\title{
THE VAI PEOPLE AND THEIR SYLLABIC WRITING
}

In the Journal of the African SOciety for October, I909, there appeared a most interesting article on "The Syllabic writing of the Vai people," by Mr. F. W. H. Migeod, Transport Officer, Gold Coast Colony.

I had seen and perused with interest the Mende Grammar from the pen of this gentleman, and so satisfied was I with the success of a book written so far away from the country where the language which it claims to teach is spoken, and by a man who has had only a meagre chance for the study of such language, that I was fully prepared to welcome Mr. Migeod's effort on the writing which the Vais believe was taught them by the great Spirit whose favourites they are.

My intention in this article is not to correct, but to corroborate and to elaborate a few points touched upon by Mr. Migeod in reference to the history and philology of the tribe with which I am identified.

The original inhabitants of the country now occupied by the Vais were the Golas, whose territory stretched from the Krim in Sherbro to the Dulu or St. Paul river near Monrovia. The Bassa, a family of the Kru tribe, mingling with the Golas in the south, amalgamated into another distinct tribe called Dé now occupying the coast between Little Cape Mount and Monrovia and speaking a language belonging more to the Bassa than to the Gola.

The Golas were salt-makers and fishermen who lived by exchanging the result of their labour with the interior tribes, who, before their amalgamation with the caast tribes and the coming of the white man $_{2}$ furnished the caast tribe with cloths and implements for farming. The present Golas, bowever, do not now occupy the sea board, nor are they any longer fishermen or sait-makers.

The Origin of the Vais.-It would seem a matter most incredible if people with talent and foresight enough to 
invent written characters of their own had been without historical facts as to how and when they first made their appearance in the country they now occupy. But they have a history, both oral or traditional and written, and therefore a basis for a literature.

The Vais are members of the great Mani (corrupted to Mandingo) family occupying that great plain from Tuba to Musardu and beyond-a tall, black, handsome and enterprising race of people-a people with knowledge of agriculture, weaving cotton, raising cattle, and working in iron and gold.

Their hunters had penetrated the various routes and scaled the spurs of the dark and mysterious Kong mountains, and had seen and tasted the waters of the great sea. Some had taken back to their homes specimens of the sea-salt with the most enchanting fairy tales of a newly found land imaginable only by the creative genius of a hunter or discoverer.

The land they had discovered was said to be all covered with salt instead of sand. Here the god of the sea sent sharp winds nightly to drive away all poisonous flies and snakes, while the noise and uproar of the gushing and splashing of the waves kept back ferocious animals from disturbing the peace of the land. Here Virgins might go and kneel before the great mother of waters, asking for gifts in recognition of chastity, when bushels of silverv sea-shells came washing up to their feet. Here at sunset gentle breezes blew softly over the land to invigorate the manhood of the people and bestow perpetual youth upon the aged. Here turtles with their golden backs sparkled as they crawled up the beach by night and deposited their ready-boiled eggs - the food of the gods-in the sand, whence any who first saw it might gather the gold dust rubbed from the shell of the golden turtles.

These were the exaggerated descriptions of the coast brought back by these hunters, which created passionate anxiety in the people of the Mani country to make their way into a land whose dust and sand were all salt.

In those days salt was made by boiling the sea-water in earthen pots of native manufacture till the water passed away in vapour, leaving a hard saline crust at the bottom, 
which was afterwards scraped and put into parcels of long bamboo leaves and cane and thus carried to adjacent villages and sold to the inhabitants, who in turn took it to a tribe farther interior and sold it at a very high price. Many had started from the land of the Manicas carrying goods and cattle to exchange for salt and never returned. Probably they were destroved by wild men or apes in the great forest between Mani and the sea. In course of time Princes arose and armed themselves, accompanied by crowds of followers, to proceed under adequate protection to the sea. Each Monarch of the Manicas placed his son or nephew at the head of his band, and so began the grand march to the West. A distinguished prince named Kamara, son of Kamara the Great of the Soudan, was amongst the leaders. He drove his horses and men through the great intervening forest, and after wandering a year came to the present site of the Konno country. There in a dense forest, but with a landscape beautiful to behold, it was suggested by some tired of the tedious journey and others timid from anticipation of a fate similar to that which befell others of their countrymen who attempted a journey to the sea, that they should remain at that point, while their brave brothers went to find the sea. Kamara agreed and said "Hn Konno Mbala ta vai" (or "fai") literally, "Wait for me while I go bravely" (or fiercely). Here was the beginning of another two distinct branches of the Manica family-the Konno or those who waited and the Vais or the braves who forced their way to the sea. As a proof of this story, in the Mandingo, Konno and Vai languages the word Konno means wait and $\mathrm{Vai}$ or Fai, brave. Although this separation took place centuries ago, yet the sameness in these languages is remarkable; especially between those of the Konno and the Vai who, after parting with the mother country, kept up communication with each other for over a century, the Waiters with the Braves.

Kamara and other brave Princes continued their journey till they saw stretched out before them the eternal sea! Kamara with spear in hand, true to the vow he had made to his father on the day of parting, drove his horse straight into the sea! Then his followers, elated at the bravery and loyalty of their leader shouted "Mansa mu ila goil Mansa 
mu ila goil Truly thou art a ruler! Truly thou art a ruler!" a title which afterwards adhered to Kamara and which for the sake of euphony became Massa-quoi. From this leader descended the ruling family of the northern part of the Vai country, known as the Gallinas country. The present writer is connected with this family.

Other great men, perhaps greater than Kamara, fixed their spears in the sand beach of what is now Mano-Salijah. Sowili, Sewalu (Sugary), Wakolo or Wakoro (now Cape Mount), and became the ancestors of such families as the Samboda, Fanbule, Golafale, Kia-Zolu, Kia-Tamba, ZoBombo, Ja-Deiba and other families of equal historical importance. Each of the above named represents a distinguished clan-which exists to this day.

It must be borne in mind that the original inhabitants of the country now occupied by the Vais were not killed out; but the men of valour from the interior married the daughters of the lords of the soil. The present race of Vais is therefore an amalgamation of Mani aliens with the indigenous Gola inhabitants. This amalgamation accounts somewhat for the medium height and light complexion of the Vais : for the ancient Golas were copper-coloured and of short stature.

As regards the invention of the Vai characters and the most recent method of prosecuting the study thereof, I reproduce here the phonetic chart of this language compiled by the writer ten years ago, and published by the Board of Missions of the Protestant Episcopal Church of America in their monthly periodical, the Spirit of Missions. It was used in the St. John's Mission School at Cape Mount and throughout the Vai country.

By means of this chart pupils have been able to read the most ancient Vai Manuscripts as well as translations from the Gospel and the Quran. The late King Dassia of the Tawa country in Liberia-a great Vai scholar but without knowledge of English letters-once visited a School at Cape Mount where a Vai class was being taught by the writer. A copy of a translation into Vai of that portion of the Iliad in which reference is made to the Fall of Troy, was placed before him. Being a rapid reader King Dassia, anticipating the class, $\operatorname{ran}$ his eyes down the manuscript and read the 
account of King Priam begging for the dead body of his son. He stopped the class while tears rolled down his cheeks, and turning to the teacher asked: "And where were Helen and Paris all this time?"

"In the city," replied the teacher.

"If I had been Priam," rejoined King Dassia, "they should never have slept within the walls of Troy that night."

The Vai character, correctly written and placed before one who has thoroughly mastered it, is easily read and understood.

Great credit is ascribed to Dualu Bukelle and his literary party; but even prior to his dream there were a few rude signs used by the Vais which did not express, but merely suggested, ideas. These signs were in the form of hieroglyphics and Dualu seems to have improved upon and utilized them thoroughly in his new compositions.

For instance,

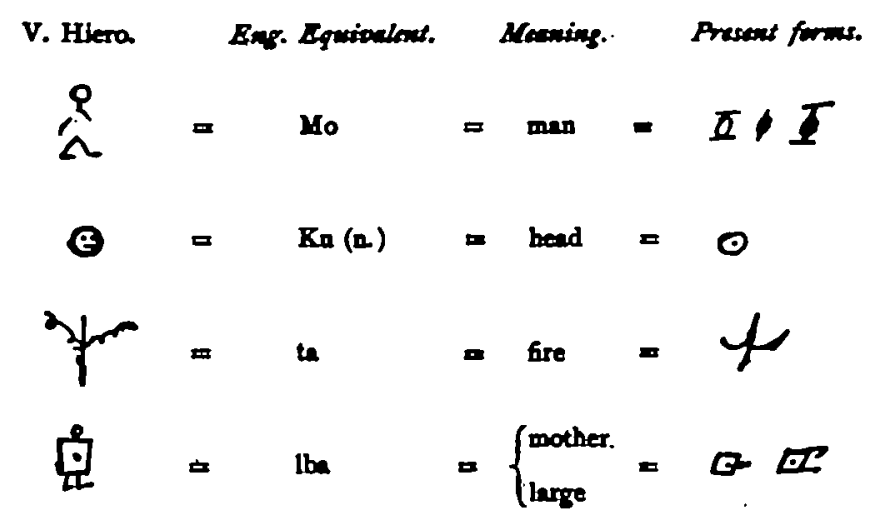

In the first example, looking at the symbol carefully, we detect a rude picture with outstretched arms and extended legs, as if in the act of walking. This represents "man." The second example is a circle with two dots within and a dash below the dots showing two eyes and mouth. This indicates "head." The third example shows a flame blazing high on both sides of the middle stroke representing sticks or wood. This symbol means "fire." The fourth plainly shows a human body with a speck within. This indicates a seed-bearing human being and stands for. 
"mother" or "large." Thus we can show the origin of scores of letters : and, teaching from the hieroglyphic origin, the characters are more easily learned and retained. The people of Tombe, a section of the Vai country now in Liberia, were the first to receive the bnok party. Here schools were first opened under shady trees and the roofs of open buildings called "barri." From Tombe the characters spread and created a "Revival of learning," and hence are called Tombe characters to this day.

In 1895 I had the pleasure of meeting in London a gentleman who, extending his hand to greet me, said: "Da, ya kune I" - familiar salutation in Vai. I was amazed to hear such good Vai (though accented) so far away from home. I replied, and conversation ensued. This gentleman was the Rev. S. W. Koelle, ${ }^{1}$ a former Missionary of the Church Missionary Society. He told me that he had visited the Vai country some twenty-five years before I was born. In the course of our interview Dr. Koelle placed before me a Manuscript written by some Vai Scholars many years before his visit, saying that he doubted if I should be able to read it. I read the manuscript and translated it to him, and he declared that my translation agreed entirely with that made to him when he was in the Vai country. Invited by Dr. Koelle, I accompanied him to Salisbury Square, where I was introduced to the Rev. Eugene Stock, who gave me the Grammar of the Vai language prepared by Dr. Koelle and a copy of the story of Ndole Wono referred to in the phonetic chart. Dr. Koelle believed that the Vai writing would be the lingua franca for a large portion of West and Central Africa : and I have gathered from a study of the comparative philology of this country that the Vai is a key to most of the ranguages spoken in the Sierra Leone Protectorate, in the North of Liberia, and in the Western Soudan.

Unfortunately every attempt at placing this language before the world and the sons of Africa has been made by foreigners. Besides the works of Koelle, Wilson and Forbes, there recently appeared a splendid treatise on this language by Monsieur Maurice Delafosse, late Consul-General of France for Liberia, which Manual was sent to me by the

Dr. Koelle died in I903-ED. 
Author for my perusal, and I found it, though brief, to be one of the best on the subject. What a pity that up to now this language is taught in none of the educational Institutions in West Africa.

That I may not appear to be advertising for employment for Vai Scholars, I would mention in this connection that tradition says that, in sending Dualu Bukelle to reveal this writing to the Vais, the Spirit distinctly forbade that anyone should accept money for teaching these characters and that the only fee for tuition should be one bottle of palm wine, a portion of which must be poured on the ground in the name of the Spirits of the book party. Upon the completion of the study a single fowl of white plumage should be given to the teacher-" Freely ye have received, freely give,"-in order that the teaching of the Spirit might go on.

A Vai man may charge a large sum for writing Vai or doing other literary work; but he will charge nothing for teaching these characters. The present writer has taught more pupils in Vai than any other living man in his country, and he has not yet received a penny for tuition. Many Europeans, with plenty of money at their disposal, have passed through his hands in Vai studies, but who first will violate the law of the great Spirit teacher?

It might appear to some that, since on the advent of the English language all native languages must vanish, the sooner Vai and others disappear the better. But it should be borne in mind that it is one thing for a man to die a natural death and another for him to be strangled or starved. To neglect these languages on the ground that some day they must die is to starve them to death, and thereby commit a philological crime. I wonder what would have been the state of things if great poets, scientists, philosophers and other geniuses were all neglected and suffered to die in the cradle on the ground that man must die?

It is a source of great comfort and encouragement to recognize the interest now taken by the British Government in Native questions, specialists having been appointed to study them, which must be taken as an interesting guarantee that England at least will not willingly allow any Native language to die; and His Majesty's Government are now requiring

30 Vol, 10 
that District Commissioners should be acquainted with at least one of the Native languages.

I see also in the Journal of the African Socuety (October, 1910) that a new periodical devoted to the Native languages of Africa and Oceania has recently made its appearance at Berlin.

It is interesting to see also that France is collecting troops in Guinee Francaise to serve, if necessary, in Europe. It is not probable that the wise officials to whose hands such duty is entrusted will collect their soldiers out of a race of shepherds or fishermen; but rather from tribes who in their native state have given indications of sterling character and warlike qualities, in whose legends there are recorded songs of Heroes who fell in battle, and who consider it as much an honour to die as to live for a good and great cause.

All tribes and all languages should be allowed and encouraged to live until the world has heard what is buried in their bosom, until their special mission has been fulfilled among the great agencies shaping the destiny of mankind, until they have exchanged thoughts with the West which may be of mutual advantage. The Vais may have a song to sing, a parable to utter, a prayer to offer or a law to interpret -all of which may be necessary elements in the progress and enlightenment of mankind. To suffer a single language to die therefore-language through the medium of which alone the soul of humanity is reached-is to rob the world of its most brilliant jewel and its most effective instrument for the uplifting and consolidation of races.

Siorra Leome,

Moyolu Massaguoi.

Nourmber 19th, 1910. 